\title{
Ultraviolet radiation and cataract: a review of the epidemiological evidence
}

\author{
Paul J Dolin
}

There is considerable international interest in the scientific community about the association between solar ultraviolet B radiation (UVB) and cataract. Much of this interest has resulted from concern about the health effects of the increasing levels of UVB reaching the earth's surface as a consequence of depletion of the stratospheric ozone layer.

Ophthalmologists have been suggesting an association between sunlight and cataract since the early part of the twentieth century. ${ }^{1-3}$ Only in the past 20 years have epidemiological studies documented the association.

Recently, polarised views have been expressed about the importance of the association. At one pole is Young who suggests that sunlight is the primary causal factor in cataractogenesis, and strongly advocates the widespread distribution of sunglasses to prevent cataract. ${ }^{4}$ At the other pole is Harding who suggests that sunlight is not a major factor in human cataract. ${ }^{5}$ These opposing views have been published recently in international ophthalmic journals and books. ${ }^{67}$ Unfortunately, ophthalmologists are left not knowing which view represents a balanced assessment of the data. The polarised assessments of Young and Harding are based on the same available evidence which strongly suggests that one, if not both, of the views is based on the selective use and interpretation of the literature.

In this review I, as an epidemiologist, assess the epidemiological information objectively to determine if there is sufficient evidence to show that exposure to solar UVB is causally associated with the development of human cataract.

\section{Study design}

Three main types of study design have been used to examine UVB and cataract: geographical correlation studies, crosssectional prevalence studies, and case-control studies. In the geographical correlation studies the prevalence of eye disease in different areas is related to non-personal factors associated with place of residence. Examples of geographical correlation studies include Hiller and colleagues' study of 35 regions of the United States, the survey of 64000 Australian aborigines by Hollows and Moran, and the survey of 28000 persons in Nepal by Brilliant and colleagues. ${ }^{8-10}$ These studies are extremely useful for generating hypotheses, but are of limited use for testing whether UVB is a cause of cataract because observed correlations may result from confounding by other factors which also vary geographically, and because the level of exposure for persons with cataract is unknown.

The second, and most common type of cataract study, has been the cross-sectional prevalence study in which a population or an occupational group is surveyed and cataract prevalence measured. Cross-sectional surveys measure all persons with the disease, some of whom will be new cases, while others may have had the disease for a considerable period of time. Some cross-sectional studies have related nonpersonal factors associated with place of residence to cataract status. Others, such as the Chesapeake Bay study and the Beaver Dam study, have collected detailed information from each participant on exposure to UVB. ${ }^{112}$ The final type of study design has been the hospital based case-control study. Cases are drawn from a hospital or clinic, while controls are drawn from other people with good vision and without cataract who were attending the same hospital or clinic. Cases and controls are then compared in relation to their UVB exposure. Both case-control and cross-sectional prevalence studies are able to test the UVB association, so most weight of evidence for a causal association will come from these studies.

\section{Cataract definition}

There has been no consistency between studies in the definition of a cataract. Some studies have only included vision reducing cataract, whereas others have included more minor lens opacities (for example, LOCS grade II or higher). Critics of the UVB association have argued that findings of studies based on low grade opacities are of limited relevance because vision reducing cataract is the disease entity of concern. Such criticisms have little epidemiological basis and, in fact, the inclusion of low grade disease is often advantageous. If UVB is shown to be causally associated with the development of low grade opacities, and one assumes that a low grade opacity will develop into a higher grade over time in the absence of intervention, then UVB exposure will also be causally associated with high grade opacities. However, the reverse inferences cannot be drawn if studies only included high grade opacities because it would not be possible to differentiate between disease causing factors and progression related factors.

Early epidemiological studies examined the UVB association for all age-related cataracts. However, as more has been learnt about the epidemiology of cataract, it has become apparent that cortical, nuclear, and posterior subcapsular cataracts should be considered as separate entities. This is because epidemiological studies suggest that the three types of cataract do not share the same set of risk factors. Most of the epidemiology studies of UVB and cataract undertaken since the late 1980s have presented separate analyses for each cataract type. The findings from the more recent studies are thus generally more informative than those of the earlier studies.

\section{Assessment of UVB exposure}

As eluded to above, two methods of exposure assessment have been used. The simplest method has been to use nonpersonal factors associated with place of residence, such as annual ambient UVB flux or annual hours of sunshine. While these measures give an estimate of exposure, they make no allowances for personal factors that determine ocular exposure, such as the number of hours spent outdoors, or for 
personal factors that may modify exposure such as the use of sunglasses. By far the best way to establish the presence and dose-response relation of the association between UVB and cataract is through studies in which exposure is individually assessed from each study participant.

\section{Studies with individual exposure assessment}

\section{CORTICAL CATARACT}

Shown in Table 1 are the findings of four studies of cortical cataract. ${ }^{11-14}$ The most informative study to date has been the Chesapeake Bay study, a cross-sectional study of watermen." The findings of this study are important because of the quality of the exposure information collected. An elaborate exposure model was developed by Rosenthal and colleagues to quantify ocular exposure to UVB. ${ }^{15}{ }^{16}$ Questionnaire information on occupational and leisure exposure to UVB since the age of 15, types of work terrain, and use of headwear and eyewear was combined with measures of ambient UVB flux and field and laboratory data to estimate cumulative exposure and average annual exposure to solar UVB. The relative risk ${ }^{\star}$ for men in the highest quartile of exposure was $3.3(95 \%$ confidence interval (CI) $0 \cdot 9-10 \cdot 0)$. The interpretation of the relative risk is that men in the highest quartile of exposure were 3.3 times more likely to have a cortical cataract than those in the lowest quartile of exposure. The Chesapeake Bay study is the only study to have examined the doseresponse relation between UVB and cortical cataract. The relative risk of cortical cataract increased with level of average annual UVB exposure. While the $95 \%$ confidence intervals for individual quartiles of exposure may not reach statistical significance, there is clearly an increase in risk with level of exposure. Logistic regression analyses revealed a significant association between total cumulative UVB exposure and cortical opacities. A doubling of cumulative exposure increased risk of cortical cataract by a factor of $1.6(95 \% \mathrm{CI}$ $1 \cdot 0-2 \cdot 6)$. When an additive dose model was fitted, watermen with cortical cataract were found to have a $21 \%$ higher average annual UVB exposure than those without cortical cataract.

The Beaver Dam study was a cross-sectional survey of the adult population of a community in Wisconsin. ${ }^{12}$ Exposure to UVB was assessed using a similar questionnaire information and exposure model as the Chesapeake Bay study. An association was found between UVB exposure and cortical cataract for males (RR $1 \cdot 4,95 \%$ CI $1 \cdot 0-1 \cdot 8$ ) but not for females (RR $0 \cdot 9,95 \%$ CI $0 \cdot 7-1 \cdot 3$ ). While the finding of an association among males confirms the findings of the Chesapeake Bay study, the lack of an association among females cannot be ignored. It is noted that women had particularly low levels of UVB exposure and a limited range of exposure. The lack of an association among the Beaver Dam women may have been due to the low levels and limited range of exposures in the female population.

The remaining studies shown in Table 1 were clinic based case-control studies in which persons attending ophthalmic clinics were categorised as either a case (those with lens opacity) or a control (those without a lens opacity). Both studies used simple qualitative measures of exposure. Participants were asked if they worked or spent leisure time in the sunlight. The Italian study found cortical cataract was associated with work location in the sunlight $(\mathrm{RR} 1 \cdot 8,95 \% \mathrm{CI}$ $1 \cdot 2-2 \cdot 6)$ and spending leisure time in the sunlight (RR 1.4, 95\% CI 1.1-1.9), whereas the Massachusetts study found no association with occupational exposure to sunlight (RR 0.9 , $95 \%$ CI $0 \cdot 6-1 \cdot 3) .{ }^{1314}$

^ The term relative risk is used throughout this review to describe measures of risk.
Table 1 Findings of cortical cataract studies with individual exposure assessment

\begin{tabular}{|c|c|c|c|}
\hline Study & Exposure & $R R$ & $95 \% C I$ \\
\hline USA, Chesapeake Bay ${ }^{11}$ & $\begin{array}{l}\text { Average annual exposure to UVB } \\
\text { quartile } 1 \\
\text { quartile } 2 \\
\text { quartile } 3 \\
\text { quartile } 4 \\
\text { Doubling of exposure }\end{array}$ & $\begin{array}{l}1 \cdot 0 \\
2 \cdot 3 \\
3 \cdot 2 \\
3 \cdot 3 \\
1 \cdot 6\end{array}$ & $\begin{array}{l}0 \cdot 7-7 \cdot 7 \\
1 \cdot 0-10 \cdot 8 \\
0 \cdot 9-10 \cdot 0 \\
1 \cdot 0-2 \cdot 6\end{array}$ \\
\hline USA, Beaver Dam ${ }^{12}$ & $\begin{array}{l}\text { Average annual exposure to UVB } \\
\text { (Wisconsin sun years) } \\
<1.01 \\
1.01+\text { Males } \\
\text { Females }\end{array}$ & $\begin{array}{l}1.0 \\
1.4 \\
0.9\end{array}$ & $\begin{array}{l}1 \cdot 0-1 \cdot 8 \\
0 \cdot 7-1 \cdot 3\end{array}$ \\
\hline USA, Massachusetts ${ }^{13}$ & $\begin{array}{l}\text { Occupational exposure to bright } \\
\text { sunshine } 2+\text { hours/day for } 2+ \\
\text { months } \\
\text { no } \\
\text { yes }\end{array}$ & $\begin{array}{l}1.0 \\
0.9\end{array}$ & $0 \cdot 6-1 \cdot 3$ \\
\hline Italy, Parma ${ }^{14}$ & $\begin{array}{l}\text { Work location in sunlight } \\
\text { no } \\
\text { yes } \\
\text { Leisure time in the sunlight } \\
\text { no } \\
\text { yes }\end{array}$ & $\begin{array}{l}1 \cdot 0 \\
1 \cdot 8 \\
1 \cdot 0 \\
1 \cdot 4\end{array}$ & $1 \cdot 2-2 \cdot 6$ \\
\hline
\end{tabular}

$\mathrm{RR}=$ relative risk $; \mathrm{CI}=$ confidence interval.

The strength of an association is indicated by the size of the relative risk estimates. The relative risk for those studies which found an association ranged from 1.4 in the Beaver Dam study and the Italian study to $3 \cdot 3$ for the highest quartile in the Chesapeake Bay study. Relative risks of this magnitude indicate that the UVB and cortical cataract association is only weak to moderate in strength. While associations of this magnitude can be causal, they could also be due to confounding by other factors associated with cataracts.

The above four studies have not demonstrated consistently an association between UVB and cortical cataract. While the Chesapeake Bay study found an association, the Beaver Dam study only demonstrated an association for males. The studies which used simple qualitative measures of exposure to sunshine had inconsistent findings. The magnitude of the relative risk estimates indicate that the UVB association is weak to moderate in strength. A dose-response relation between UVB and cortical cataract for men was shown in the Chesapeake Bay study. Further studies are currently being undertaken to confirm the dose-response relation.

\section{POSTERIOR SUBCAPSULAR CATARACT}

Shown in Table 2 are the results of posterior subcapsular cataract studies in which exposure was assessed for each study participant. The Maryland study is a clinic based case-control study in which cases were persons attending for a posterior

Table 2 Findings of posterior subcapsular cataract studies with individual exposure assessment

\begin{tabular}{|c|c|c|c|}
\hline Study & Exposure & $R R$ & $95 \% C I$ \\
\hline USA, Maryland ${ }^{17}$ & $\begin{array}{l}\text { Cumulative exposure to UVB } \\
\text { Average annual exposure to UVB }\end{array}$ & & $\begin{array}{l}p=0.001 \\
p=0.001\end{array}$ \\
\hline USA, Beaver Dam ${ }^{12}$ & $\begin{array}{l}\text { Average annual exposure to UVB } \\
\text { (Wisconsin sun years) } \\
<1 \cdot 01 \\
1 \cdot 01+\text { Males } \\
\quad \text { Females }\end{array}$ & $\begin{array}{l}1 \cdot 0 \\
1 \cdot 2 \\
1 \cdot 1\end{array}$ & $\begin{array}{l}0.8-1 \cdot 7 \\
0.7-1 \cdot 7\end{array}$ \\
\hline USA, Massachusetts ${ }^{13}$ & $\begin{array}{l}\text { Occupational exposure to bright } \\
\text { sunshine } 2+\text { hours/day for } 2+ \\
\text { months } \\
\text { no } \\
\text { yes }\end{array}$ & $\begin{array}{l}1 \cdot 0 \\
1 \cdot 3\end{array}$ & $0 \cdot 7-2 \cdot 3$ \\
\hline Italy, Parma ${ }^{14}$ & $\begin{array}{l}\text { Work location in sunlight } \\
\text { no } \\
\text { yes } \\
\text { Leisure time in the sunlight } \\
\text { no } \\
\text { yes }\end{array}$ & $\begin{array}{l}1.0 \\
1.8 \\
1.0 \\
0.6\end{array}$ & NS \\
\hline
\end{tabular}

$\mathrm{RR}=$ relative risk $; \mathrm{CI}=$ confidence interval; $\mathrm{NS}=$ not significant. 
subcapsular cataract extraction and controls were other people attending the clinic who did not have a history of posterior subcapsular cataract. ${ }^{17}$ Cumulative UVB exposure and average annual UVB exposure were estimated using the same methods as the Chesapeake Bay study. Cases were found to have higher $(p=0.001)$ cumulative UVB exposure and annual UVB exposure than controls. When exposure was fitted as a continuous variable in a logistic model, risk was found to increase with level of exposure (trend $p=0.006$ ). Two other case-control studies, from Massachusetts and Italy, also examined posterior subcapsular cataract but neither found an association between exposure to sunlight and cataract risk. ${ }^{13}{ }^{14}$

In the Chesapeake Bay study data on posterior subcapsular cataract could not be analysed because less than $2 \%$ ( 14 cases) of the study group had posterior subcapsular cataract. ${ }^{11}$ The Beaver Dam study found $6 \%$ of the population had posterior subcapsular cataract (162 males and 118 females), but no association was found between posterior subcapsular cataract and average annual UVB exposure for either males or females. ${ }^{12}$

An association between UVB and posterior subcapsular cataract has not been demonstrated consistently. The strongest evidence comes from the Maryland study. The remaining studies provide little support for an association. The relative risk estimates in the above studies ranged from 0.6 in the Italian study to 1.3 in the Massachusetts study. Relative risk of this size indicated that an association between UVB and posterior subcapsular cataract is at most weak in magnitude.

\section{NUCLEAR CATARACT}

Presented in Table 3 are the findings from six nuclear cataract studies in which individual exposure was assessed. ${ }^{11-14} 1819$ None of the studies found an association between UVB and nuclear cataract, including those in which detailed exposure information was collected. Collectively these data suggest there is a lack of an association with nuclear cataract.

\section{MIXED OUTCOME STUDIES}

There have been several studies with individual exposure assessment which have presented analyses for all age-related cataract, rather than for specific cataract types. ${ }^{18-20}$ Table 4 shows the findings from these studies. It is noted that none of the studies found an association with exposure to sunlight. As

Table 3 Findings of nuclear cataract studies with individual exposure assessment

\begin{tabular}{|c|c|c|c|}
\hline Study & Exposure & $R R$ & $95 \% C I$ \\
\hline USA, Chesapeake Bay ${ }^{11}$ & $\begin{array}{l}\text { Average annual exposure to UVB } \\
\text { lowest quartile } \\
\text { highest quartile }\end{array}$ & $\begin{array}{l}1 \cdot 0 \\
1 \cdot 0\end{array}$ & $0 \cdot 4-2 \cdot 6$ \\
\hline USA, Beaver Dam ${ }^{12}$ & $\begin{array}{l}\text { Average annual exposure to UVB } \\
\text { (Wisconsin sun years) } \\
<1.01 \\
1.01+\text { Males } \\
\text { Females }\end{array}$ & $\begin{array}{l}1 \cdot 0 \\
0.9 \\
1.0\end{array}$ & $\begin{array}{l}0 \cdot 8-1 \cdot 1 \\
0 \cdot 8-1 \cdot 2\end{array}$ \\
\hline USA, Massachusetts ${ }^{13}$ & $\begin{array}{l}\text { Occupational exposure to bright } \\
\text { sunshine } 2+\text { hours/day for } 2+\text { months } \\
\text { no } \\
\text { yes }\end{array}$ & $\begin{array}{l}1 \cdot 0 \\
0.5\end{array}$ & $0 \cdot 3-0 \cdot 9$ \\
\hline \multirow[t]{2}{*}{ Italy, Parma ${ }^{14}$} & $\begin{array}{l}\text { Work location in sunlight } \\
\text { no } \\
\text { yes }\end{array}$ & $\begin{array}{l}1.0 \\
0.6\end{array}$ & $\mathrm{p}<0.05$ \\
\hline & $\begin{array}{l}\text { Leisure time in the sunlight } \\
\text { no } \\
\text { yes }\end{array}$ & $\begin{array}{l}1 \cdot 0 \\
1 \cdot 2\end{array}$ & NS \\
\hline USA, N Carolina ${ }^{18}$ & $\begin{array}{l}\text { Lifetime exposure to sunlight } \\
\text { low } \\
\text { high }\end{array}$ & $\begin{array}{l}1.0 \\
0.8\end{array}$ & $0 \cdot 4-2 \cdot 0$ \\
\hline USA, Iowa ${ }^{19}$ & Lifetime exposure to sunlight & \multicolumn{2}{|c|}{ no association } \\
\hline
\end{tabular}

$\mathrm{RR}=$ relative risk; $\mathrm{CI}=$ confidence interval; $\mathrm{NS}=$ not significant.
Table 4 Findings of mixed outcome studies with individual exposure assessment

\begin{tabular}{|c|c|c|c|}
\hline Study & Exposure & $R R$ & $95 \% C I$ \\
\hline USA, N Carolina ${ }^{18}$ & $\begin{array}{l}\text { Lifetime exposure to sunlight } \\
\text { low } \\
\text { high }\end{array}$ & $\begin{array}{l}1 \cdot 0 \\
1 \cdot 1\end{array}$ & $0 \cdot 6-2 \cdot 0$ \\
\hline USA, Iowa ${ }^{19}$ & Lifetime sunlight exposure & \multicolumn{2}{|c|}{ no association } \\
\hline Hong Kong ${ }^{20}$ & $\begin{array}{l}\text { Sunlight exposure score } \\
\text { grade II v grade } 0 / 1 \text { opacity } \\
\text { low } \\
\text { high }\end{array}$ & $\begin{array}{l}1 \cdot 0 \\
1 \cdot 2\end{array}$ & $0 \cdot 6-2 \cdot 8$ \\
\hline & $\begin{array}{l}\text { grade III v grade } 0 / 1 \text { opacity } \\
\text { low } \\
\text { high }\end{array}$ & $\begin{array}{l}1 \cdot 0 \\
2 \cdot 1\end{array}$ & $0 \cdot 6-7 \cdot 9$ \\
\hline
\end{tabular}

$\mathrm{RR}=$ relative risk $; \mathrm{CI}=$ confidence interval .

these studies do not present analyses for specific types of cataract, few inferences can be drawn from the findings. Because of these limitations the findings from these studies are of limited importance.

\section{Studies with exposure assignment based solely on place of residence}

Several studies have based exposure assignment on factors associated with place of residence, such as annual ambient UVB flux or annual hours of sunshine in the area of residence. The findings from such studies need to be interpreted with care as they are subject to what has been termed the ecological fallacy. The data are not based on the exposure status of individuals and it is not known if persons with cataract have more or less UVB exposure than other persons living in the same residential area.

The findings from three geographical correlation studies undertaken in different regions of the world in which exposure was based solely on place of residence are shown in Table $5{ }^{8-10}$ One of the earliest epidemiological studies of UVB and cataract was undertaken by Hiller and colleagues. ${ }^{8}$ Data on the prevalence of cataract were collected in the National Health and Nutrition Survey of 35 geographic areas of the United States during 1971-2. The average annual hours of sunlight in each of the 35 areas was estimated from US weather bureau maps. The prevalence of cataract was found to be higher in those areas with highest hours of sunlight. Among persons aged $65-74$, the prevalence of cataract in areas with $3000+$ annual hours of sunlight was around $2 \cdot 7$ times that of areas with less than 2400 hours of sunlight. A similar trend is also evident for persons aged 45-64. Further analyses using data on ambient UVB flux at each study

Table 5 Findings from studies with exposure assignment based solely on place of residence

\begin{tabular}{|c|c|c|c|}
\hline Study & Geographical factor & $\begin{array}{l}\text { Preval- } \\
\text { ence } \\
\text { ratio }\end{array}$ & $\begin{array}{l}95 \% \\
C I^{\star}\end{array}$ \\
\hline \multirow[t]{2}{*}{$\begin{array}{l}\text { USA, } 35 \text { areas } \\
\text { NHANES survey data }\end{array}$} & $\begin{array}{l}\text { Annual hours of sunlight in area } \\
\text { Ages } 45-64 \\
<2400 \text { hours } \\
2600-2800 \text { hours } \\
3000+\text { hours }\end{array}$ & $\begin{array}{l}1 \cdot 0 \\
1 \cdot 1 \\
1 \cdot 6\end{array}$ & $\begin{array}{l}0 \cdot 6-1 \cdot 8 \\
0 \cdot 8-2 \cdot 9\end{array}$ \\
\hline & $\begin{array}{l}\text { Ages } 65-74 \\
<2400 \text { hours } \\
2600-2800 \text { hours } \\
3000+\text { hours }\end{array}$ & $\begin{array}{l}1 \cdot 0 \\
1 \cdot 7 \\
2 \cdot 7\end{array}$ & $\begin{array}{l}1 \cdot 2-2 \cdot 7 \\
1 \cdot 6-4 \cdot 6\end{array}$ \\
\hline Australia9 & $\begin{array}{l}\text { Average mean erythemal dose of area } \\
\text { Age } 60+ \\
<1000 \\
1000-1999 \\
2000-2499 \\
2500-2999 \\
3000+\end{array}$ & $\begin{array}{l}1 \cdot 0 \\
1 \cdot 8 \\
2 \cdot 2 \\
2 \cdot 2 \\
2 \cdot 2\end{array}$ & $\begin{array}{l}0 \cdot 5-5 \cdot 7 \\
0 \cdot 7-6 \cdot 8 \\
0 \cdot 7-7 \cdot 0 \\
0 \cdot 7-6 \cdot 8\end{array}$ \\
\hline $\mathrm{Nepal}^{10}$ & $\begin{array}{l}\text { Average hours of sunlight } \\
\text { low }(7-9 \text { hours }) \\
\text { medium }(10-11 \text { hours }) \\
\text { high }(12+\text { hours })\end{array}$ & $\begin{array}{l}1 \cdot 0 \\
1 \cdot 2 \\
2 \cdot 5\end{array}$ & $\begin{array}{l}0 \cdot 9-1 \cdot 4 \\
2 \cdot 1-3 \cdot 0\end{array}$ \\
\hline
\end{tabular}

$\star 95 \%$ confidence intervals estimated from published data. 
location showed prevalence of cataract was significantly correlated with ambient UVB flux. ${ }^{21}$ Analysis by cataract type revealed that this association was specific for cortical cataract. ${ }^{22}$

A study of Australian aborigines related prevalence of cataract to a number of environmental factors. ${ }^{9}$ Cataract was found to be correlated with hours of sunlight and mean erythemal dose (a biological measure of UVB exposure). A second study from Australia also found an association between prevalence of cataract and ambient UVB levels. ${ }^{23}$

A cataract prevalence survey of 97 rural villages in Nepal examined how prevalence varied with hours of sunlight and altitude. ${ }^{10}$ The prevalence of cataract in villages with 12 hours of sunlight was 2.5 times that of villages with 7-9 hours of sunlight. It is noted that this study found an inverse relation between prevalence of cataract and altitude, with highest prevalence occurring in villages at lowest altitude. The lack of a positive association in this study between altitude and prevalence of cataract appears inconsistent, and has been suggested by sceptics of a UVB role as evidence for the lack of an association. The apparent inconsistency can be explained by the terrain of the study areas. The low altitude villages were located on the flat terai near the Indian border and in fact had the highest number of hours of sunlight. Conversely, the villages in the hills and Himalayas, located between 350 and 2300 metres of altitude had fewer hours of sunlight, presumably because of the shadowing effects of the Himalayas.

The findings of the above geographical correlation studies are consistent in showing an association between ambient UV and prevalence of cataract. While these studies do not have information on exposure for each individual they provide extremely good ecological support for the findings of the Chesapeake Bay and Beaver Dam studies.

\section{Supporting biological data}

There is good experimental evidence from in vivo and in vitro studies to demonstrate that exposure to artificial sources of UVB, such as lasers, causes lens opacities in laboratory animals. ${ }^{24-29}$ It is not clear what the exact mechanism is that leads to opacification of the lens. Several possible mechanisms have been suggested including tryptophan degradation leading to decreased levels of ATPase and increased levels of free radicals, and UVB damage to the lens epithelium leading to a calcium imbalance in the membrane. ${ }^{30-32}$

While the mechanisms of cataractogenesis are yet to be fully understood, the important issue for this review is not the mechanism but whether the experimental data support the epidemiological data. Animal studies clearly show that UVB causes opacities in laboratory animals. However, the cortical opacities produced in animal studies have a different morphology from that found in human cortical opacities. The animal opacities mainly occur in the anterior cortical region of the lens whereas human cortical opacities tend to occur in the equatorial (peripheral) parts of the cortical region.

The interpretation of these differences is that the animal species used to date are not perfect models of the human lens. However, the ability to produce experimentally lens opacities in animal species with long term low dose UVB irradiation provides useful support for the epidemiological data.

\section{Evidence of causation}

An elaborate set of guidelines were put forward by BradfordHill and have been widely used in epidemiology as the framework for assessing causation. ${ }^{33}$ In deciding if there is sufficient evidence to conclude that an association is causal several criteria must be considered: consistency of association, strength of association, presence of a dose-response relation, supporting evidence from ecological studies, and supporting evidence from laboratory studies.

There is good supporting ecological evidence for an association. The findings of geographical studies based on place of residence have consistently demonstrated an association between prevalence of cataract and meteorological factors, such as annual hours of sunshine. The prevalence of cataract has been shown to be higher in locations with increased hours of sunshine.

There is ample experimental evidence to support the association. Data from experimental studies have shown that exposure to artificial sources of UVB causes lens opacities in laboratory animals. While it is noted that the opacities produced in animal models are not all morphologically identical to those found in humans, the experimental data provide support for the hypothesis that exposure to solar UVB can cause lens opacities in humans.

However, the epidemiological studies have not consistently found an association with UVB exposure. The most convincing epidemiological evidence that exposure to solar UVB causes human lens opacities comes from the Chesapeake Bay and Beaver Dam studies. The Chesapeake Bay study found a clear dose-response relation between level of exposure and risk for cortical opacities, but this is yet to be confirmed. The Beaver Dam study found exposure to UVB was related to risk of cortical opacities for males but failed to find an association for females, although this could reflect the low levels of exposure among females. Studies from Massachusetts and Italy used simpler measures of personal exposure but found conflicting results. When observed, the association is at most weak to moderate in strength.

Conflicting findings have been reported for posterior subcapsular cataracts. The Maryland study found a statistically significant relation between exposure to UVB and posterior subcapsular cataract. However, other studies found no association. The dose-response relation between level of exposure and cataract risk has yet to be documented.

There is little, if any, evidence that exposure to UVB causes nuclear opacities in humans. None of the epidemiological studies in which individual exposure was assessed found an association.

\section{Conclusions}

Based on the available epidemiological evidence, the following conclusions are drawn about exposure to UVB being a cause of cataract.

(1) There is sufficient experimental evidence that exposure to artificial sources of UVB can cause lens opacities in laboratory animals.

(2) There is only limited evidence that exposure to solar UVB causes cortical opacities in humans.

(3) There is only limited evidence that exposure to solar UVB causes posterior subcapsular cataract in humans.

(4) The epidemiological evidence is consistent in suggesting that nuclear cataracts are not causally associated with exposure to solar UVB.

These conclusions represent a unbiased assessment of the evidence and fall between the views of Harding and Young. There is, without doubt, an association between exposure to UVB and cortical opacities. Currently there are insufficient epidemiological data to show that the association is causal. I was invited to provide a review of the epidemiological evidence for a World Health Organisation meeting in September $1993 .^{34}$ The conclusions presented here are consistent with those reached by the WHO meeting.

Further epidemiological studies of cataract are required. Such studies should be undertaken in different populations to demonstrate that a UVB association occurs across a range of exposures. Exposure needs to be assessed in an elaborate 
manner similar to that used in the Chesapeake Bay and Beaver Dam studies. Lifetime exposure history needs to be collected, including exposure during childhood, to enable the dose-response relation to be examined.

The call for immediate implementation of preventive strategies must be viewed with caution. From a public health viewpoint a decision must be made at the earliest opportunity regarding the implementation of preventive strategies. However, it is not currently known what percentage of cataract cases and, particularly, visually disabling cataract, in different populations is attributable to UVB exposure. An intervention can only prevent that proportion of cataract cases which is attributable to UVB exposure. Without this knowledge the justification for, and potential impact of, prevention strategies cannot be estimated. This issue is particularly important from the global viewpoint. The vast majority of cataract cases occur in developing countries where resources are limited. The introduction of a preventive programme aimed at reducing ocular exposure to UVB could divert real funds away from other effective prevention of blindness programmes.

International Centre for Eye Health,

PAUL J DOLIN

Institute of Ophthalmology,

Bath Street

London ECIV 9EL

1 Birch-Hirschfeld A. Die pathologische wirkung der strahlenden energie auf das auge. 1: Blendung duch sonnenlicht. Ergebn Allg Path des Menschen und der Tiere 1914; 16: 619-34.

2 Verhoeff FH, Bell L, Walker CB. The pathological effects of radiant energy on the eye. Proc Am Acad Sci 1916; 51: 1-810.

3 Duke-Elder WS. The pathological action of light upon the eye. Part II. Action upon the lens: theory of the genesis of cataract. Lancet 1926; i: 1188-91.

4 Young RW. Optometry and the preservation of visual health. Optom Vis $S_{c i}$ 1993; 70: 255-62.

5 Harding JJ. Physiology, biochemistry, pathogenesis, and epidemiology of cataract. Curr Opinion Ophthalmol 1992; 3: 3-12.

6 Young RW. Age related cataract. New York: Oxford University Press, 1991.

Harding JJ. Cataract: biochemistry, epidemiology and pharmacology. London: Chapman \& Hall, 1991 .

8 Hiller R, Giacometti L, Yuen K. Sunlight and cataract: an epidemiologic investigation. $A m \mathcal{F}$ Epidemiol $1977 ; 105: 450-9$.

9 Hollows F Moran D Cataract-the ultraviolet factor Lancet 1981; ii: 1249-50.

10 Brilliant LB, Grasset NC, Pokhrel RP, Kolstad A, Lepkowski JM, Brilliant $\mathrm{GE}$, et al. Associations among cataract prevalence, sunlight hours, and altitude in the Himalayas. Am $\mathcal{F}$ Epidemiol 1983; 118: $250-64$.
11 Taylor HR, West SK, Rosenthal FS, Munoz B, Newland HS, Abbey H, et al. Effect of ultraviolet radiation on cataract formation. N Englf Med 1988; 319: $1429-33$

12 Cruickshanks KJ, Klein BE, Klein R. Ultraviolet light exposure and lens opacities: the Beaver Dam Eye Study. Am f Public Health 1992; 82: 1658-62. 3 Leske MC, Chylack LT, Wu SY, The Lens Opacities Case-Control Study Group. The lens opacities case-control study: risk factors for cataract. Arch Ophthalmol 1991; 109: 244-51.

14 Italian-American Cataract Study Group. Risk factors for age-related cortical, nuclear, and posterior subcapsular cataracts. Am F Epidemiol 1991; 133: $541-53$

15 Rosenthal FS, Bakalian AE, Taylor HR. The effect of prescription eyewear on ocular exposure to ultraviolet radiation. Am f Public Health 1986; 76: 1216-20

16 Rosenthal FS, Phoon C, Bakalian AE, Taylor HR. The ocular dose of ultraviolet radiation to outdoor workers. Invest Ophthalmol Vis Sci 1988; 29: 649-56.

17 Bochow TW, West SK, Azar A, Munoz B, Sommer A, Taylor HR. Ultraviolet light exposure and risk of posterior subcapsular cataracts. Arch Ophthalmol 1989; 107: 369-72.

18 Collman GW, Shore DL, Shy CM, Checkoway H, Luria AS. Sunlight and other risk factors for cataracts: an epidemiologic study. Am $\mathcal{F}$ Public Health 1988; 78: $1459-62$.

19 Dolezal JM, Perkins ES, Wallace RB. Sunlight, skin sensitivity, and senile cataract. Am $\mathcal{A}$ Epidemiol 1989; 129: 559-68.

20 Wong L, Ho SC, Coggon D, Cruddas AM, Hwang CH, Ho CP, et al. Sunlight exposure, antioxidant status, and cataract in Hong Kong fishermen. f Epidemiol Community Health 1993; 47: 46-9.

21 Hiller R, Sperduto RD, Ederer F. Epidemiologic associations with cataract in the 1971-1972 National Health and Nutritional Examination Survey. Am 7 Epidemiol 1983; 118: 239-49.

22 Hiller R, Sperduto RD, Ederer F. Epidemiologic associations with nuclear, cortical and posterior subcapsular cataract. Am $\mathcal{F}$ Epidemiol 1986; 124: 916-25.

23 Taylor HR. The environment and the lens. Brf Ophthalmol 1980; 64: 303-10. 4 Bachem A. Ophthalmic ultraviolet action spectra. Am 7 Ophthalmol 1956; 41 : 969-75.

25 Zigman S, Yulo T, Schultz J. Cataract induction in mice exposed to near UV light. Ophthalmol Res 1974; 6: 259-70.

26 Zigman S, Graff J, Yulo T, Vaughen T. The response of mouse ocular tissue to continuous near-UV light exposure. Invest Ophthalmol 1975; 14: 710-3.

27 Pitts DG, Cullen AP, Hacker PD. Ocular effects of ultraviolet radiation from 295 to $365 \mathrm{~nm}$. Invest Ophthalmol Vis Sci 1977; 16: 932-9.

28 Jose JG, Pitts DG. Wavelength dependency of cataract in albino mice following chronic exposure. Exp Eye Res 1985; 41: 545-63.

29 Jose JG. Posterior cataract induction by UVB radiation in albino mice. Exp Eye Res 1986; 42: 11-20.

30 Zigman S. Photobiology of the lens. In: Maisel H, ed. The ocular lens: structure, function and pathology. New York: Marcel Dekker, 1985; 301-47.

31 Hightower K, McCready J. Mechanisms involved in cataract development following near ultraviolet radiation of cultured lens. Curr Eye Res 1992; 11 : 679-89.

32 Hightower K, McCready J. Physiological effects of UVB irradiation on cultured rabbit lens. Invest Ophthalmol Vis Sci 1992; 33: 1783-7.

33 Bradford-Hill A. The environment and disease: association or causation? Proc $R$ Soc Med 1965; 58: 295-300.

34 World Health Organisation. Informal consultation on the effects of solar UV-radiation on the eye. WHO/PBL/93.34. Geneva: WHO, 1994 (in press). 